\title{
Эпизод из истории литературных контактов: рецепция сочинений Франца Костера SI в книжной культуре Речи Посполитой XVI-XVII вв.
}

\author{
М. А. КОРЗО \\ Институт философии РАН, ул. Гончарная, д. 12/1, RU-109240 Москва \\ E-mail:ma.korzo@gmail.com
}

(Received: 3 January 2017; accepted: 24 March 2017)

\begin{abstract}
The history of the ascetic works composed by the Flemish Jesuit Franz Coster (1531-1619) and their translations into Polish and "prosta mova" are considered as an interesting example of the 17th-century literary contacts in Europe and an example of the spread of Catholic works among adherents of Orthodoxy. Coster's Bulla super forma iuramenti professionis fidei (1576) was originally intended to members of the Catholic Sodality of the Blessed Virgin Mary in Cologne. Two Polish-language reversed editions entitled Skarb duszny (1582 and 1594) served as a source of a concise text of admonition written in "prosta mova" to the confession Nauka i priklady, which can be found in two editions of the 17th-century Orthodox Vilna's Poluustav: ca. 1637-1640 and ca. 1643-1644. The Polish translation later was taken as a basis for drawing up a manual of confession Nauka o tainie svyatogo pokayaniya (1671) published in the Kiev Monastery of the Caves. The question of the translator from Latin into Polish as well as the translator from Polish into "prosta mova" remains open.
\end{abstract}

Keywords: Franz Coster, Polish-Lithuanian Commonwealth, literary contacts, Orthodox religious literature

История литературных связей в XVI-XVII вв. представляет собой весьма благодатное поле для исследователя. Одной из форм взаимодействия различных книжных традиций можно назвать переводческую деятельность, нацеленную на популяризацию на национальных языках латинских памятников религиозного содержания. Переводы сочинений подобного рода зачастую не упоминали об их истинных авторах; случалось и так, что переводчики сами не имели об этом представления. Такое «умолчание» авторства было вполне естественно, когда речь шла о восходящих еще к Средневековью анонимных молитвенниках, сборниках благочестивых размышлений и различного рода аскетико-назидательных памятниках. Другое дело, если речь шла об авторских сочинениях XVI в. и автором выступал значимый для церковной среды деятель.

В настоящем исследовании будет рассмотрен лишь один из эпизодов подобного рода книжных контактов, но эпизод весьма примечательный, поскольку речь идет о распространении латинского текста не только в иных языковых средах, но также и в иной конфессиональной реальности: и в данном случае - о функционировании католического памятника в православной 
книжности. При этом перевод на иной «конфессиональный язык» с необходимостью требовал обращения к определенным переводческим техникам, поскольку речь шла о сглаживании догматических различий и о приведении католической религиозной терминологии в соответствие с православным понятийным аппаратом. В нашем случае своего рода посредником в переводе с латинского языка на т. н. «простую мову» или литературный язык православных Речи Посполитой послужил польский язык.

Бельгиец Франц Костер (Franz [François] Coster, 1531-1619) принадлежал к первому поколению иезуитов. Получив образование в Риме и Лювене, после 1556 г. он преподавал в Collegium Tricoronatum в Кёльне, исполнял обязанности провинциала и ректора коллегий Общества Иисуса в бельгийском Брюгге и французском Дуэ. Костер снискал славу талантливого богослова, был автором многочисленных назидательных и аскетических сочинений, пропагандировавших в первую очередь различные формы марийной духовности. Именно ему принадлежит инициатива создания на рубеже $1575-$ 1576 гг. при кёльнской коллегии иезуитов Марианской Содалиции - религиозного общества для студентов, практикующих поклонение Деве Марии (Andriessen 1964, Brzosa 2001: 448, Meuthen 1988: 354-355, Mostaccio 2014: 46-47). Костер был известен и как талантливый полемист и автор учебника по полемическому богословию Enchiridion controversiarum praecipuarum nostri temporis (Coloniae, 1585) (BACKER-SOMMERVOGEL 1811: 1510-1534).

Польская библиография фиксирует единственный случай публикации сочинения Костера в Речи Посполитой и перевода его на польский язык. Речь идет о небольшом трактате о т. н. «четырех последних вещах» или о смерти, посмертном суде, аде и рае. Латинская версия De quatuor novissimis vitae humanae была издана в 1603 и 1605 гг. в краковской типографии Шимона Кемпини, а в 1606 году у Миколая Лоба вышло из печати немецкоязычное издание. Трактат Костера привлек внимание известного польского иезуита Петра Скарги (1536-1612), который переложил его на польский язык. Перевод был опубликован дважды в 1606 г. в Кракове у активно сотрудничавшего с иезуитами типографа Анджея Пётрковчика (ESTREICHER 1896: 430-431, BACKERSOMMERVOGEL 1811: 1518-1520). ${ }^{1}$ Скарга несколько расширил текст, добавив в приложении раздел «Przydatek y Summariusz, o tychże czterech końcach ostatnich żywota ludzkiego» в форме кратких «размышлений» и адресованных читателю практических предостережений (KOMOROWSKA 2012: 382-383, KowZAN 2002). В предисловии к переводу польский иезуит признается, что он только недавно познакомился с трактатом Костера в латинской версии. ${ }^{2}$ Речь идет, судя по всему, об упомянутых выше краковских изданиях. Данное замечание Скарги можно также осторожно интерпретировать таким образом, что он ранее вообще не был знаком с сочинениями своего кёльнского собрата.

\footnotetext{
${ }^{1}$ Полное название сочинения Костера в переводе Скарги «О czterech końcach ostatnich żywota ludzkiego: y o wielce pożytecznym rozmyślaniu ich».

${ }^{2}$ «...w starości siedmdziesętletney będąc» (c. 3), то есть в возрасте 70 лет или в 1606 г. 
De quatuor novissimis vitae humanae Костера не было самостоятельным сочинением, а частью его более пространного труда, известного под названием Libellus Sodalitatis, hoc est: Christianarum Institutionum libri quinque. Опубликованный впервые в 1586 г. в Антверпене, Libellus переиздавался до конца XVI в. еще как минимум шесть раз (Кёльн, 1586; Антверпен, 1587, 1588; Ингольштадт, 1588 [исправленная версия], 1597; Лион, 1594), ${ }^{3}$ что может свидетельствовать о востребованности данного сочинения. De quatuor novissimis образует третий раздел Libellus.

В предисловии к данному трактату Костер останавливается на истории его создания. Считается, что большинство аскетико-назидательных сочинений бельгийского иезуита были отражением его активной пастырской деятельности: они создавались как на основе его проповедей и произнесенных ранее поучений, так и на основе наставлений для членов опекаемой им Марианской Содалиции в Кёльне (BRzosa 2001: 448, Meuthen 1988: 354-355, Mostaccio 2014: 46-47). В предисловии к Libellus Костер еще раз подтверждает, что взялся за создание данного труда именно для нужд Содалиции и что первоначальная версия сочинения вышла из печати под названием Bulla и состояла из трех частей; со временем же он расширил свой труд за счет рассуждений о «четырех последних вещах» и толкований на Апостольский символ веры, молитвы «Отче наш» и «Радуйся, Мария». ${ }^{4}$

Сочинение, которое имеет в виду Костер - это Bulla super forma iuramenti professionis fidei; cum piis christianis Institutionibus, in usum Sodalitatis B. Mariae Virginis (Кёльн, 1576). До конца XVI в. было еще как минимум два переиздания с аналогичным названием (Кёльн, 1577 и Ингольштадт, 1579). Важно отметить, что все три издания совершенно идентичны по содержанию и были опубликованы без указания авторства Костера. Предисловие датировано 24.IX.1576, разрешение церковных властей на публикацию - июлем 1575 г. В литературе встречается мнение, что Bulla отражает содержание устных поучений Костера, обращенных к членам Содалиции (MILLER 1934: 101). Тот факт, что сочинение было одобрено к публикации уже в 1575 г., то есть еще до официального создания Марианского общества в Кёльне в 1576 г., позволяет поставить под сомнение эту версию. Роль своего рода вступления в анализируемом сочинении играет раздел, который и дал название всему труду: «Bulla S.D. N.D. Pii Divina providentia papae IIII. super forma iuramenti professionis fidei». Он представляет собой исповедание веры, составленное и утвержденное по результатам заседания Тридентского собора (1545-1563).

\footnotetext{
${ }^{3}$ У Костера было еще одно сочинение с очень похожим названием (Manuale Sodalitatis, sive Christianarum Institutionum libellus), но совершенно иным содержанием.

${ }^{4}$ «...exijt igitur Libellus sub nomine Bullae... Ad tres igitur libros, qui hactenus in lucem prodierunt, duos alios adiunxi, et ex priori tertium facere opportunum mihi visum est, quod de meditationibus agat novissimorum humanae vitae, quae non parum ad vitia omnia depellenda ac propulsanda momenti habent. Posterior ultimo loco explicat Orationem Dominicam, Salutationem Angelicam, et Apostolorum Symbolum» (Coloniae, 1603, s. 6-6v; экз. Herzog August Bibliothek, Wolfenbüttel, шифр Xb 5783).
} 
Далее в трех частях оговариваются последовательно практики подготовки к исповеди и причастию, излагается учение об основных категориях греховных поступков и лекарствах против них, объясняются основные части католического богослужения и описываются предметы одеяния церковнослужителей, содержится толкование отдельных католических религиозных традиций и практик. В приложении помещен ряд документов, связанных с учреждением Марианских Содалиций («Regulae seu ordinationes Confraternitatis Beatissimae Virginis Mariae, institutae inter studiosos Collegii SI Coloniensis» и булла Григория XIII от 10.IX.1577 на основание Содалиции), и отдельные богородичные гимны, литании и молитвы, предназначенные для ежедневных благочестивых практик членов данного объединения.

Параллельно с Bulla, а именно уже с 1578 г., данное сочинение Костера начинает публиковаться совершенно под другим названием как Thesaurus Piarum et christianarum Institutionum in usum catholicae iuventutis. Praesertim vero Sodalitatis Deiparae Virginis. До конца столетия вышли из печати два его переиздания в Диллингене (1583 и 1591 гг.). Во всех трех случаях было сохранено предисловие из Bullae, датированное 24.IX.1576 г., но было сокращено число приложений, а также «Regulae et Ordinationes» были адресованы уже не только кёльнской Содалиции, но подобным марийным объединениям всех иезуитский коллегий в германских землях («Collegiorum SI in Germania»). Тридентское исповедание веры было перенесено в конец сочинения. Именно на основе Thesaurus Piarum в последствии создавались переводы на национальные языки. ${ }^{5}$ Самым примечательным изменением было появление на титульном листе упоминания об авторе труда - о некоем Йоханнесе Переллиусе (Johannes Perellius). Было ли сочинение отредактировано самим Костером или его издателями, а также принадлежала ли идея с псевдонимом самому бельгийскому иезуиту - ответить на эти вопросы не представляется возможным. ${ }^{6}$ Не удалось также установить, использовал ли Костер данный псевдоним в каких-либо иных работах. Известно лишь, что в книговедческих изданиях с XIX в. псевдоним «Johannes Perellius» отождествляется исключительно с именем Костера (WeLLER 1977: 421).

Анализируемое нами сочинение кёльнского иезуита в то же самое время публиковалось и с третьим вариантом названия как Piarum et christianarum Institutionum libri tres (Coloniae, 1581). ${ }^{7}$ В данном случае издания выходили как без указания его истинного автора, так и без псевдонима. Можно предположить, что основой для Piarum et christianarum Institutionum послужила скорее первоначальная версия сочинения Bulla, а не Thesaurus Piarum, поскольку Тридентское исповедание веры снова оказывается в самом начале

${ }^{5}$ Самый ранний перевод - на немецкий язык: Schatzbüchlein oder Wegweiser der gnadenreichen Sodalitet der H. Mariae (Ингольштадт, 1579, 1588; Мюнстер, 1614, 1623).

${ }^{6}$ Бельгийские библиографы XVIII века, например, не отождествляли данное сочинение с именем Костера (FOPPENS 1739: 289-290).

${ }^{7}$ Очередные издания: Дуэ, 1582; Вена, 1583; Диллинга, 1583; Дуэ, 1585; Льеж, 1586; Милан, 1586. 
книги, а на обороте титула помещен стих из Bullae «Catholico pioque lectori»; также «Regulae seu Ordinationes» адресованы, как и в Bullae, исключительно членам кёльнской Содалиции. В приложении появляется совершенно новый текст «Jubilus Sancti Bernardi Abbati».

Именно под таким названием и в таком составе анализируемое нами сочинение Костера было впервые опубликовано в Польше - в познаньской типографии Яна Вольраба в 1583 г. ${ }^{8}$ Можно только строить предположения о том, почему именно данная книга была выбрана для публикации. Не удалось также установить, были ли у Познани какие-то особые тесные контакты с собратьями в Кёльне. Известно лишь, что Вольраб очень активно сотрудничал с коллегией Общества Иисуса в Познани, а иезуиты охотно обращались в его типографию и финансировали необходимые им издания (KAWECKA-GRYCzowA et al. 1977: 273, 275). Сочинение Костера могло предназначаться для нужд местной Марианской Содалиции, созданной в 1574 г., а в 1582 г. расширенной за счет так называемой «старшей» Содалиции - или объединения для старших учеников коллегии (BIELAWNy 2009: 331, GRZEBIEŃ-WIESIOŁOWSKI 2004: 28). Отметим в качестве примечания, что в отдельных изданиях Libellus Sodalitatis (например: Кёльн, 1603 и 1610) на титульном листе помещена гравюра Девы Марии с Иисусом в образе ребенка на облаках. Очень похожую гравюру мы встречаем и в познаньском издании Вольраба. В его версии, правда - это гравюра с выраженными ренессансными чертами (KAWECKAGRYCZOWA et al. 1977: 278), в то время как в кёльнских изданиях начала XVII века гравюра пронизана скорее духом посттридентского благочестия.

Вольраб или заказавшие ему публикацию иезуиты, судя по всему, сами не знали, что издают работу Костера - Libellus с его именем вышел из печати тремя годами позднее, в 1586 г. Стоит отметить, что и в современной польской библиографии Piarum et christianarum Institutionum все еще не идентифицируется с именем кёльнского иезуита, а фигурирует без указания авторства (ESTREICHER 1901: 583).

Примечательно также, что познаньский издатель не знал, что уже годом ранее в Кракове был опубликован перевод данного сочинения Костера на польский язык. В качестве основы для перевода была выбрана, судя по всему, версия под названием Thesaurus Piarum, поскольку перевод называется аналогичным образом: Skarb duszny. Польской библиографии известны два издания данной книги: 1582 г. без указания места печати и типографа ${ }^{9}$ и 1594 г. как продукцию краковской типографии Анджея Пётрковчика. ${ }^{10}$ Хотя в обоих случаях на титуле указано, что сочинение вновь переведено с латинского

${ }^{8}$ Institutionum. Piarum et Christ. Institutionum Libri tres, in usum Sodalitatis B. Mariae Virginis primum conscripti, nunc vero omnium Christianorum Pietati ac Deuotioni destinati vna cum S.D. N.D. Gregorij XIII. Ponti. Max. dictae sodalitatis aprobatione gratijs et indulgentijs eidem Sodalitati concessis (экз. Biblioteka Zakładu Narodowego im. Ossolińskich, Wrocław, шифр XVI.0.25).

9 Экз. Biblioteka Narodowa, Warszawa, шифр XVI.0.6193.

10 Экз. Biblioteka Jagiellońska, Kraków, шифр Cim. 994; Biblioteka Uniwersytetu Warszawskiego, шифр 28.1.15.29. 
языка на польский («teraz nowo z Łacińskiego języka na Polski przełożony» [курсив - М. К.]), представляется малоправдоподобным, что существовали какие-либо более ранние издания этого текста. Книги совершенно идентичны с точки зрения содержания (ESTREICHER 1930: 127) и графического оформления, что позволяет предположить, что обе версии были продукцией типографии Пётрковчика.

Как и в случае с латиноязычным изданием Костера у Яна Вольраба, Пётрковчик также, вероятно, не знал, кто был автором сочинения, которое он публикует. Польский издатель снабдил книгу предисловием (аналогично в обеих версиях), в котором кратко остановился на достоинствах сочинения, но ни словом не упомянул о том, какой же труд лежит в основе перевода. В польское издание не попали все без исключения тексты, помещенные у Костера в приложении; Тридентское исповедание веры было опубликовано в самом конце книги, уже после содержания. ${ }^{11}$ Подобная издательская стратегия может свидетельствовать о том, что Пётрковчик (или переводчик?) попытался придать данной книге более универсальный характер, адресовав Skarb duszny более широкому кругу читателей, а не только членам Марианских Содалиций. Может быть, именно по этой причине перевод и вышел из печати без указания автора (если он вообще был на тот момент известен), чтобы не отпугнуть потенциального читателя, который по каким-либо причинам был скептично настроен по отношению к письменной продукции заграничных иезуитов.

Невозможно в настоящий момент ответить на вопрос, кто взял на себя труд перевести Thesaurus Piarum на польский язык. Этот человек, вне всякого сомнения, или принадлежал к Обществу Иисуса, или был связан с близкими к иезуитам кругами. Им мог быть и сам Пётрковчик, который активно с Обществом сотрудничал и может быть по праву назван одним из основных издателей сочинений иезуитов в Кракове (KoMOROWSKA 2014).

Польский перевод дословно воспроизводит латинский оригинал. Единственным отличием можно считать появление во второй части сочинения в контексте полемики с иноверцами о пользе практики частого причащения ссылки на некое сочинение De frequenti communione («Szczypacze y nieprzyiaciele częstego przystępowania/niech czytaią książki Łacińskim ięzykiem napisane: De frequenti communione»; Skarb duszny 1594: 66). Подобного фрагмента нет у Костера во всех версиях его сочинения, нет также и в латинском издании Вольраба.

В данном случае речь идет скорее всего о сочинении итальянца Иеронима Каччагуэрры (Cacciaguerra, 1494/1495-1566), которое было написано первоначально на итальянском языке (REGAZZONI 2002: 352). Самый ранний из известных библиографии латинских переводов был опубликован в 1586 г.

${ }^{11}$ Текст цитируется по изданию 1594 г. из собраний Музея книги РГБ, № 10931. Экземпляр дефектный, без титульного листа и предисловия, издательские данные помещены на последнем листе. 
Впоследствии латиноязычная версия трактата Каччагуэрры часто издается под одной обложкой с сочинением с аналогичным названием испанского доминиканца, богослова и мистика Луиса де Гранады (1504-1588). Хотя уже в отдельных переводах на национальные языки до 1586 г. трактат Каччагуэрры фигурирует именно в латинской версии как De frequenti communione. ${ }^{12}$

Сама по себе данная ссылка не вызывает удивления: известно, что католические богословы той эпохи и в первую очередь иезуиты активно пропагандировали практику частого причастия и обосновывали данную практику в многочисленных сочинениях. Не отставали от своих западных собратьев и польские члены Общества Иисуса, которые обращались к проблеме частого причастия чаще всего в контексте антипротестантской полемики. Так, Петр Скарга в своем сочинении Siedm Filarów na których stoi Katolicka nauka o przenaświętszym Sakramencie Ottarza (SKARGA 1582) опровергает мнение своих конфессиональных оппонентов, что «[мы] Catholicy lud wierny Christusow od używania tego przenaświętszego Sakramentu odganiamy, a ledwie ich raz w rok albo dwa przypuszczaiąc do tey niebieskiey potrawy» (k. 227). И далее у Скарги следует раздел «Pięcioraka podniąta która serca ludu Bożego do częstego używania przenaświętszego Sakramentu podniecamy» (k. 230). Если уже существовали польскоязычные памятники на тему частого причастия, то возникает вопрос, почему переводчик Костера на польский язык предпочел указать читателю не на эти более доступные для него сочинения, но на латиноязычный трактат? Ответить на этот вопрос пока не представляется возможным.

Если не знать об изначальном назначении сочинения Костера, но проанализировать его в дошедшем до нас польском переводе - то есть без всех дополнительных текстов, связанных с культом Девы Марии, то очень сложно однозначно определить жанр данной книги. Ее никак нельзя назвать в строгом смысле слова катехизисом, хотя она и включает элементы изложения вероучения. Пространный раздел о подготовке к исповеди позволяет отнести Skarb duszny к разряду пособий по таинству покаяния. Большое место в книге отведено толкованию католического богослужения и обрядности, следовательно, сочинение можно поставить в один ряд с мануале по литургике. ${ }^{13}$ Исследователи типографского наследия Анджея Пётрковчика отнесли, например, Skarb duszny к жанру молитвенников (KAWECKA-GRYCZOWA 1983: 154).

${ }^{12}$ Примером может послужить немецкий перевод 1571 г.: De frequenti Communione. Aussfürlicher Bericht und erklärung von der Communion... durch D. Philippum Dobereiner... auss dem Hieronymo Cacciaguerra verdolmetscht, Dilingen.

${ }^{13}$ Толкование отдельных частей богослужения встречается в ту эпоху довольно редко в сочинениях, адресованных простым верующим. К числу исключений можно отнести популярный молитвенник польского иезуита Мартина Латерны (Marcin Laterna, ок. 1552-1598) Harfa duchowna (Краков, 1585), отдельные сочинения Луиса де Гранады (Wizerunek żywota chrześcijańskiego pobożnego..., Poznań: Jan Wolrab, 1584; экз. Biblioteka Narodowa, Warszawa, XVI.0.927), единичные издания немецких молитвенников XVI в. (например, Außerlesen gulden Schatzbüchlein Christlichen andechtigen Katholischen Gebett, Köln, 1571, л. 40ff.). В более ранний период это были Hortulus animae ([Нюрнберг], 1521; Антверпен, 1564) и известный Speygel der leyen (Любек, 1496, л. 7-21об.). 
Подобная тематическая широта сочинения Костера в его польской версии могла предопределить популярность данной книги в Речи Посполитой: Skarb duszny использовался и для нужд религиозной формации в женских монастырях бенедиктинок: известно, что сестры заказали эту книгу ок. 1590 г. для библиотеки новой филии монастыря в Несвеже (GóRSKI 1971: 43). Но самое удивительное, что популярность сочинения Костера в Речи Посполитой (пусть и в его анонимной форме) не ограничивалась лишь кругом приверженцев католицизма: этот труд привлек внимание и православных авторов.

Речь идет о двух эпизодах переложения Костера на т. н. «простую мову» - литературный язык православных Киевской митрополии. В обоих случаях за основу было взято одно из краковских изданий Пётрковчика, на что указывает значительное число полонизмов в переводах. Польский язык, как это зачастую случалось в Речи Посполитой в XVII в., выступил своего рода посредником между латинской книжностью и книжностью приверженцев православия Киевской митрополии.

Первый эпизод связан с публикацией двух Полууставов виленского православного братства: первый из них датируется в библиографии ок. 1637 1640 гг., ${ }^{14}$ второй - ок. 1643-1644 гг. ${ }^{15}$ Издания практически тождественны по содержанию, но речь идет о разных типографских наборах, о чем свидетельствует отличающаяся пагинация сборников.

Полуустав как разновидность богослужебной книги и в ту эпоху, и позднее издавалась только в православных типографиях Речи Посполитой и совершенно не представлена среди печатной продукции Московского Печатного двора. А. В. Вознесенский считает, что данный тип богослужебной книги является разновидностью следованной Псалтири (ВознЕсенский 1996). Но при этом книговеды отмечают, что в более поздних изданиях под названием Полуустав (например: Киев, 1682 и Вильно, 1695) Псалтирь могла вообще отсутствовать, и эти издания, таким образом, представляли собой совершенно иной тип богослужебной литературы (КАМЕНЕВА 1959: 281).

В вышеназванных изданиях виленских Полууставов после раздела «Правило Мнишеское» встречается фрагмент назидательного характера «Наука и приклады, до частого спасеннаго исповеданїя греховъ». Данное поучение составлено т. н. «простой мовой» и этим оно отличается от других статей Полуустава, написанных на церковнославянском языке местного извода. «Наука и приклады» организована как последовательный перечень примеров, призванных побудить верующего к более частой, регулярной исповеди, когда нечистая совесть сравнивается то с грязным одеянием или немытыми волосами, то с неприбранным помещением и нестиранными скатертями, то с сидящими по углам пауками, чьи сети напоминают сети дьявола. В более поздних По-

${ }^{14}$ Цитируется по экз. МК РГБ, инв. 2489, без титульного листа (Кніга Беларусі 1986: № 136). Все известные экземпляры дефектные. Принято считать, что издание не могло быть завершено ранее 1640 г., поскольку пасхалии начинаются именно с этого года.

${ }^{15}$ Цитируется по экз. МК РГБ, инв. 6626 (Кніга Беларусі 1986: № 148). 
лууставах братства, таких как Полуустав великий 1646 г. (ГАЛЕНЧАНКА 1986: № 152) и в Полууставе Вильно 1695 г. (ГАЛЕНчАнКА 1986: № 174) данного или подобного ему поучения об исповеди уже не встречается. Таким образом, можно сделать вывод, что «Наука и приклады» появляется эпизодически в виленских Полууставах ок. 1640 г., а потом совершенно исчезает. Именно этот фрагмент и был позаимствован из польского издания Костера Skarb duszny: мы имеем дело с дословным переводом 2-й главы «Wywody przez podobieństwa krociuchne y każdemu człowiekowi ku poięciu łacne do zalecenia częstey spowiedzi» (c. 14-19oб.)

Кириллический текст воспроизводит польский текст дословно, хотя и с отдельными сокращениями. Так, например, исключается большой фрагмент из начальной порции текста, где грех рассматривается по аналогии с денежным долгом, при возвращении которого человек получает расписку или некое свидетельство. Это могло ассоциироваться с практикой т. н. «отпустов» или милосердных лет, когда отпущение грехов сопровождалось получением свидетельства в форме индульгенции. Не вошли в перевод и фрагменты об исповеди как форме самопознания; о том, что исповеданию грехов предшествует некая упреждающая благодать, без которой исповедь невозможна.

Исследователи уже давно не ставят под сомнение то, что православные авторы Киевской митрополии были хорошо знакомы с книжной продукцией иных конфессиональных кругов и активно обращались к ней в своем богословском творчестве. Процессам заимствований не препятствовало даже открытое противостояние сторонников православия и католицизма в этом регионе. ${ }^{16}$ Но наряду с этими общими и очевидными констатациями бывает сложно ответить на вопрос, почему именно тот или иной памятник привлек внимание православных книжников; почему виленские братчики при таком обилии как польских, так и переводных наставлений об исповеди решили перевести именно фрагмент краковского издания Костера конца XVI в. Также недостаточная сохранность и исследованность источников виленского братства середины XVII в. позволяет только строить предположения о том, кто конкретно взял на себя труд переложить польский текст на «простую мову». ${ }^{17}$

Второй эпизод перевода сочинения Костера на литературный язык православных Киевской митрополии связан с издательской деятельностью КиевоПечерской Лавры, в стенах которой было подготовлено и опубликовано в качестве самостоятельного издания пособие по исповеди под названием «Наука о тайне святого покаяния〉 (Киев, 1671). На титульном листе указано, что работу над сочинением благославил архимандрит Лавры Иннокентий Гизель (ок. 1600-1683 гг.).

${ }^{16}$ Стоит отметить, что католическими памятниками не чурались и перебравшиеся в Россию выходцы из Речи Посполитой (КоРзо 2011), а также и демонстрировавшие свое открытое неприятие католицизма сторонники т. н. «грекофильской партии» в Москве (КоРзо 2014: 88-98).

${ }^{17}$ Выражаю свою благодарность литовскому историку Дариусу Баронасу за консультацию по современному состоянию исследований братского движения в Вильно. 
Предисловие к «Науке» не упоминает о ее польских или латинских источниках или прототипах, хотя уже используемая в памятнике богословская терминология наводит на мысль о том, что его составители обращались к каким-то польскоязычным сочинениям - в тексте достаточно много полонизмов (КиСельОв 2009: 141-146). Skarb duszny был использован далеко не в полном объеме: были переведены лишь те порции текста, которые непосредственно связаны с таинством исповеди, с практикой испытания совести, с анализом различных категорий грехов и «лекарств» против них. В таблице приведены лишь те фрагменты польского текста, которые вошли в киевскую Науку в полном объеме:

\begin{tabular}{|c|c|}
\hline Наука 1671 г. & Skarb duszny (1594) \\
\hline $\begin{array}{l}\text { Заключительные рассуждения преди- } \\
\text { словия «Каючомуся Чителнику, Наука» } \\
\text { [л. 4об.-5об.] }\end{array}$ & $\begin{array}{l}\text { Составлено из фрагментов раздела } \\
\text { «Sposob spowiedzi» [10oб.-11об.] }\end{array}$ \\
\hline $\begin{array}{l}\text { [11-18об.] Часть Первая, Рахованя сво- } \\
\text { еи Совъсти, в которой припоминается, } \\
\text { яковым способом выступует человекъ } \\
\text { против Богу, и Ближнему, и самому } \\
\text { себъ. }\end{array}$ & $\begin{array}{l}\text { [3-8] Krociuchne rozbieranie sumnienia, } \\
\text { ile z strony Boga. Jako y czym człowiek } \\
\text { przeciwko iemu występuie/albo wystapić } \\
\text { może... Z strony Blizniego... Z strony } \\
\text { siebie samego. }\end{array}$ \\
\hline $\begin{array}{l}\text { [18об.-31об.] Часть вторая. В которой- } \\
\text { ся припоминаетъ, якъ Человекъ грьшит } \\
\text { против Десяти Приказанїй Божіих. }\end{array}$ & $\begin{array}{l}\text { [23-32oб.] Rozbieranie sumnienia, z stro- } \\
\text { ny przykazania Bożego. }\end{array}$ \\
\hline $\begin{array}{l}\text { [31об.-33об.] Часть третяя, О седми } \\
\text { грђхах смертелных, и прочїихъ грђхах, } \\
\text { которїи ся от них родят. А напрод } \\
\text { о Гордости, всьх грђхов Царици. }\end{array}$ & $\begin{array}{l}\text { [32об.-34об.] O siedmi głownych grze- } \\
\text { chach. A naprzod o krolowey grzechow } \\
\text { wszystkich Paniey Pysze. }\end{array}$ \\
\hline $\begin{array}{l}\text { [33об.-35об.] О седми цоркахъ Гор- } \\
\text { дости }\end{array}$ & $\begin{array}{l}\text { [34oб.-36] O siedmi corkach prożney } \\
\text { chwały }\end{array}$ \\
\hline [35об.-40] О Лакомствђ & [36-37] O Lakomstwie \\
\hline [40-42об.] О нечистоть & [37oб.-39] O Nieczystości \\
\hline [42об.-45] О Заздрости & [39-41] O Zazdrości \\
\hline [45-47об.] О Гньвђ & [41об.-43] O Gniewie \\
\hline [47об.-52] О обжирствђ & [43-45] O Obżarstwie \\
\hline [52-57] О ЛЬнивствђ & [45об.-48] O Lenistwie \\
\hline $\begin{array}{l}\text { [57-62об.] О грђхах чужихђ, которыхъ } \\
\text { ест рожай осморакїй }\end{array}$ & $\begin{array}{l}\text { [48об.-51 об.] O dziewiąci grzechach } \\
\text { cudzych }\end{array}$ \\
\hline $\begin{array}{l}\text { [62об.-65об.] О околичностях гръхов- } \\
\text { ныхъ }\end{array}$ & [52-53] O okolicznościach grzechowych \\
\hline $\begin{array}{l}\text { [66-66об.] О предсявзятю, и о сродках } \\
\text { до поправы живота. } \\
\text { [67-68] Лъкарства на Грьхи }\end{array}$ & $\begin{array}{l}\text { [12-13oб.] O przedsięwzięciu y o srzod- } \\
\text { kach do poprawy żywota }\end{array}$ \\
\hline
\end{tabular}




\begin{tabular}{|c|c|}
\hline $\begin{array}{l}\text { [69-73об.] ЛЬкарство противъ Гордыни } \\
\text { и Тщеславїя }\end{array}$ & $\begin{array}{l}\text { [165oб.-167oб.] Lekarstwa przeciwko } \\
\text { Prożney chwale }\end{array}$ \\
\hline $\begin{array}{l}\text { [73об.-76] ЛЬкарство противко заздро- } \\
\text { сти }\end{array}$ & $\begin{array}{l}\text { [171-172oб.] Lekarstwa przeciwko } \\
\text { Zazdrości }\end{array}$ \\
\hline $\begin{array}{l}\text { [76-79об.] ЛЬкарство противко лаком- } \\
\text { ства }\end{array}$ & $\begin{array}{l}\text { [167oб.-170] Lekarstwa przeciwko } \\
\text { Łakomstwu }\end{array}$ \\
\hline [79об.-84] ЛЬкарство противко гнђву & $\begin{array}{l}\text { [173-175об.] Lekarstwa przeciwko } \\
\text { Gniewu }\end{array}$ \\
\hline $\begin{array}{l}\text { [84-87об.] ЛЬкарство противъ обжир- } \\
\text { ству }\end{array}$ & $\begin{array}{l}\text { [175об.-177oб.] Lekarstwa przeciwko } \\
\text { Obżarstwu }\end{array}$ \\
\hline $\begin{array}{l}\text { [87об.-91об.] ЛЬкарство противко не- } \\
\text { чистоть }\end{array}$ & $\begin{array}{l}\text { [170-171] Lekarstwa przeciwko Nie- } \\
\text { czystości }\end{array}$ \\
\hline $\begin{array}{l}\text { [91об.-94] ЛЪкарство противъ льнив- } \\
\text { ству ку службъ Божой }\end{array}$ & $\begin{array}{l}\text { [177oб.-179] Lekarstwa przeciwko Le- } \\
\text { nistwu ku Służbie Bożey }\end{array}$ \\
\hline $\begin{array}{l}\text { [94-96об.] Способъ якъся отоучити от } \\
\text { злого звычаю присяганя }\end{array}$ & $\begin{array}{l}\text { [159oб.-161] Srzodki ku wykorzenieniu } \\
\text { złego zwyczaiu przysięgania }\end{array}$ \\
\hline $\begin{array}{l}\text { [96об.-101] Наука, якся научити чест } \\
\text { отдавати Родичом и Старшим }\end{array}$ & $\begin{array}{l}\text { [161-164] Co będzie służyło ku czczeniu } \\
\text { Rodziców y Starszych }\end{array}$ \\
\hline [101-104] ЛŁкарство на оклеветанїе & [164-165об.] Lekarstwa na obmawianie \\
\hline $\begin{array}{l}\text { [104-113] Выводы короткїи през Подо- } \\
\text { бенства, кождому человеку ку понятю } \\
\text { снадные якъ то ест речъ пожитечнаа } \\
\text { часто сповъдатися }\end{array}$ & $\begin{array}{l}\text { [14-19oб.] Wywody przez podobieństwa } \\
\text { krociuchne /y każdemu człowiekowi ku } \\
\text { poięciu łacne do zalecenia częstey spo- } \\
\text { wiedzi }\end{array}$ \\
\hline
\end{tabular}

Как следует из сравнения, лаврские издатели также совершили некоторую композиционную перестановку: так, они изменили последовательность «лекарств» на отдельные смертные грехи и «Wywody przez podobieństwa krociuchne», опубликованные уже ранее в составе виленских Полууставов и помещенные в польском оригинале в начале первой части, оказались в заключительной части Науки. На этот раз данный раздел был переведен полностью, без сокращений. Несмотря на то, что книгообмен в пределах Киевской митрополии функционировал весьма исправно и киевское духовенство было знакомо с книжной продукцией типографий Великого княжества Литовского, велика вероятность того, что в данном конкретном случае лаврские издатели вообще не знали о предшествующем опыте перевода данного фрагмента.

Наука 1671 г. не всегда слепо придерживается польского оригинала. Редакторская правка состояла, в первую очередь, в некотором расширении и дополнении содержания: переводчик не вводит никаких новых сюжетов, но обогащает текст рядом деталей, отражающих повседневные практики приверженцев православия (особенности постов, контакты с иноверным окружением и др.).

Установление польского источника Науки 1671 г. позволяет окончательно опровергнуть встречающееся в литературе предположение, что данное 
сочинение могло быть сокращенной или адаптированной версией изданного в Лавре двумя годами ранее фундаментального труда по нравственному богословию «Мир с Богом человеку». При этом в дальнейшем продумывании нуждается высказанная Л. Довгой гипотеза, что издание обоих сочинений почти одновременно не было случайностью и что их надо рассматривать в контексте всего комплекса реформ, инициированных в Киевской митрополии еще митрополитом Петром Могилой (ДовГА 2010: 188-190).

Как и в случае с виленскими Полууставами, невозможно установить, почему издатели Лаврской типографии обратились именно к краковскому изданию более чем вековой давности и кто был его переводчиком. К числу возможных переводчиков (составителей) точно не принадлежал тогдашний архимандрит Лавры Иннокентий Гизель, поскольку он не владел языком, на котором составлялась Наука.

Это был последний эпизод издания сочинения бельгийского иезуита Костера «простой мовой» в XVII в., но не последний эпизод распространения данного сочинения среди православных: в 1686 г. на землях современной западной Украины была сделана рукописная копия Науки 1671 г., ${ }^{18}$ и с этого момента сочинение Костера получает хождение также и в рукописной форме. ${ }^{19}$

\section{Литература}

ANDRIESSEN 1964 = ANDRIESSEN Jos: Costerus, Franciscus. In: National Biografisch Woordenboek I. Brussel, 1964. 333-341.

BACKer-Sommervogel 1811 = De BACKer d'Alois, Sommervogel Charles: Bibliothèque de la Compagnie de Jésus II. Bruxelles-Paris, 1811.

Bielawny 2009 = Bielawny Krzysztof: Kongregacje Mariańskie w Polsce w latach 15711914. Ateneum Kaptańskie 2009/3: 331-345.

Brzosa 2001 = BRzosa Ulrich: Die Geschichte der katholischen Kirche in Düsseldorf. Von den Anfängen bis zur Säkularisation. Köln-Weimar-Wien, 2001.

ESTREICHER 1896 = ESTREICHER Karol: Bibliografia polska 14. Kraków, 1896.

ESTREICHER 1901 = ESTREICHER Karol: Bibliografia polska 18. Kraków, 1901.

ESTREICHER 1930 = ESTREICHER Karol: Bibliografia polska 28. Kraków, 1930.

FoPPENS 1739 = FopPENS Johannes Franciscus: Bibliotheca Belgica, sive vivorum in Belgio vita, scriptisque illustrium catalogus, librorumque nomenclatura I. Bruxellis, 1739.

GóRSKI 1971 = GóRSKI Karol: Matka Mortęska. Kraków, 1971.

GrZeBIEŃ-WiesIOŁOwSKi 2004 = GrZeBIEŃ L. TJ, WiesIOŁOwSKi J. (red.) Kronika Jezuitów poznańskich (mlodsza) I. Poznań, 2004.

Kawecka-Gryczowa 1983 = Kawecka-Gryczowa A. (red.) Drukarze dawnej Polski od XV do XVIII wieku. T. 1. Cz. 1. Wrocław, 1983.

Kawecka-Gryczowa et al. 1977 = Kawecka-Gryczowa A., Korotajowa K., SójKa J. (red.) Drukarze dawnej Polski od XV do XVIII wieku. T. 3. Cz. 1. Wrocław, 1977.

\footnotetext{
${ }^{18}$ Библиотека им. В. Стефаныка НАН Украины во Львове. Собрание монастыря Василиан МВ-532. Л. 1-106.

${ }^{19}$ Исследователи согласны в том, что не только в XVII веке, но и в последующем на территории Киевской митрополии «рукописи как и прежде доминировали в церковных и монастырских собраниях, а также в частных библиотеках» (TOPOLSKA 1983: 144).
} 
KOMOROWSKA 2012 = KOMOROWSKA Magdalena: „Nowoczesność” staropolskich przekładów literatury religijnej (na przykładzie tłumaczeń Piotra Skargi). In: HeJMOwsKi K. et al. (red.) Ttumacz: stuga, pośrednik, twórca? Warszawa, 2012. 377-388.

KOMOROWSKA 2014 = KOMOROWSKA Magdalena: Książki jezuickich pisarzy w polskich oficynach drukarskich przełomu XVI i XVII wieku (na przykładzie drukarni Andrzeja Piotrkowczyka). In: CyBUlski Ł., KoEHLER K. (red.) Retoryka Towarzystwa Jezusowego i jej konteksty. Warszawa, 2014. 141-154.

KowZAN 2002 = KowZAN Jacek: Franciszek Coster i Piotr Skarga. Dwa utwory ,de quattuor hominis novissima" - próba analizy porównawczej. Prace Literackie 41 (2002): 65-74.

MEUTHEN 1988 = MEUTHEN Erich: Kölner Universitätsgeschichte I. Köln-Wien, 1988.

Miller 1934 = Miller Josef: Die Marianischen Kongregationen im 16. und 17. Jahrhundert: ihr Wesen und ihr marianischer Charakter. Zeitschrift für katholische Theologie 58 (1934): 83-109.

Mostaccio 2014 = Mostaccio Silvia: Early Modern Jesuits between Obedience and Conscience during the Generalate of Claudio Acquaviva (1581-1615). Farnham, 2014.

REgAZzoni 2002 = RegAzzoni Mauro: L'epoca delle riforme e della Controriforma. In: Zovatto P. (ed.) Storia della spiritualità italiana. Roma, 2002. 223-442.

Skarb duszny 1594 = Skarb duszny nad złoto y kamienie drogie kosztownieyszy: zamykaiac w sobie niemal wszystkie pobożne prawych chrześcijanow ćwiczenia. Kraków, 1594.

SKARga 1582 = SKarga Piotr: Siedm Filarów na których stoi Katolicka nauka o przenaświętszym Sakramencie Ottarza. Wilno, 1582.

TOPOLSKA 1983 = TOPOLSKA Maria: Biblioteki w Wielkim Księstwie Litewskim w XVI i pierwszej połowie XVII wieku. Pamiętnik Biblioteki Kórnickiej 20 (1983): 143-183.

WELLER 1977 = WeLLER Emil: Lexicon Pseudonymorum. Wörterbuch der Pseudonymen aller Zeit und Völker oder Verzeichnis jener Autorem, die sich falscher Namen bedienten. Hildesheim-New York, 1977.

ВОЗНЕСЕНСКИЙ 1996 = ВОЗНЕСЕНСКИЙ А. В. Служебная Псалтирь в восточнославянском книгопечатании XVI-XVIII вв. Труды Отдела древнерусской литературы. Т. 50. Санкт-Петербург, 1996. 215-219.

ГАЛЕНЧАНКА $1986=$ ГАЛЕНЧАНКА Г. Я. (ред.) Кніга Беларусі: 1517-1917. Зводны каталог. Мінск, 1986.

ДовГА 2010 = ДовГА Лариса: Наука про покуту в украӥнських текстах XVII cm. В кн.: ДовгА Лариса (ред.): Інокентій Гізель. Вибрані твори у 3 томах. Т. 3. Київ-Львів, 2010. 167-193.

КАMEHEBA 1959 = КАMEHEBA Т. Н. Черниговская типография, ее деятельность и издания (XVII-XVIII вв.). Трудь Государственной библиотеки им. В. И. Ленина. Т. 3. Москва, 1959. 224-384.

КисельОв 2009 = КисеЛЬОВ Роман: Термінологічні паралелі видань «Наука о тайні святого покаянія» (Київ, 1671) та «Мир з Богом чоловіку» (Київ, 1669). Київська Академія 7 (2009): 141-146.

КоРзо 2011 = КоРзо М. А. Нравственное богословие Симеона Полоикого. Освоение католической традиции московскими книжниками второй половины XVII века. Москва, 2011.

КоРзо 2014 = КоРзо М. А. О некоторых изданиях Киевской митрополии в рукописном наследии Евфимия Чудовского. Славяноведение 2014/2: 88-98.

Наука 1671 = Наука о тайне святого покаяния. То есть, о правдивой и сакраменталной исповеди. Киев, 1671. 